\title{
Serum Ferritin as a Risk Factor for Myocardial Infarction
}

\author{
M S Hafiz ${ }^{1}$, M I Arslan ${ }^{2}$, S Banarjee $^{3}$, M Obaidullah $^{4}$
}

\begin{abstract}
Myocardial Intarction (MI) is the most common form of heart disease and the single most important cause of premature death in the developed and developing world. Unfortunately the incidence of the condition is Increasing rapidly in many developing countries like Bangladesh. Effort should therefore be taken to minimize the risk factors of Mi. There are several studies which evaluate the relation of serum ferritin with MI in abroad. In Bangladesh, there is no such study was carried out to evaluate the relationship between serum ferritin and MI. So the present work has been designed to evaluate the association of serum ferritin with $\mathrm{MI}$.
\end{abstract}

The present study was carried out in the Department of Biochemistry, BSMMU in collaboration with Department of Cardiology, BSMMU and NICVD, Dhaka during the period of July 2001 to December 2002. A total of 50 subjects were selected, Group A ( 20 subjects of MI) and Group B (30 subjects of Control). The mean level of serum ferritin in control subjects were 111.65 \pm $50.47 \mathrm{ng} / \mathrm{ml}$ and in test subjects were $258.44 \pm 87.87 \mathrm{ng} / \mathrm{ml}$. So the present study showed that serum ferritin level is significantly higher in patients with MI. From the present study, it is difficult to draw any definite conclusion but suggested that high serum ferritin concentration may be a cause of the incidence of MI.

TAJ 2003; $16(1): 5-7$

\section{Introduction}

Myocardial Infarction (MI) is the most common form of heart disease.' Unfortunately the incidence of the condition is increasing rapidly in many developing countries like Bangladesh. Diseases of the cononary arteries is almost always due to atheroma and its complications, particularly thrombosis. The major risk factors for MI are family history, DM, smoking, hypertension and lipid. ${ }^{2}$ Excess serum ferritin as a risk factor for MI is a relatively newer concept since the early $1980{ }^{3}$
Ferritin is a large protein shell having molecular weight $450 \mathrm{KDa}$ comprised of 24 subunits, covering an iron core containing upto 4000 atoms of iron. Ferritin acts as the soluble storage form of iron in tissue. ${ }^{4}$ High serum ferritin may increase the risk of $\mathrm{MI}$ in the presence of other risk factors, that increase the formation of free radicals, thus accelerating atherogenesis via stimulation of LDL oxidation. ${ }^{5}$ In Bangladesh, there is no such study to evaluate the relationship between serum ferritin and MI. So the present work has been designed to evaluate the association of serum ferritin with Ml.

'Lecturer, Oepartment of Elochemistry, Rajshahi Medical College, Rajshahi.

a Professor \& Chaiman. Department of Biochemistry. BSMMU, Dhaka.

s Associale Prolessor, Departmenl of Cardiology, ESMMU, Dhaka.

4 Associate Professor, Department of Biochemstry. Rajshahi Medical College, Majshahi. 


\section{Materials and methods}

A cross sectional comparative study was done. The test subjects were diagnosed by history, clinical examination and different investigations like ECG, Echo, ETT \& CAG. The control subjects had no symptoms and signs of $\mathrm{MI}$ and had no predisposing factors related to MI. detected on the basis of history clinical examination and ECG. Age and sex were matched. Data were collected through a preformed data collection sheet (questionnaire). Blood sample was collected and questionnaire was filled up. Data were expressed in various forms as presentation and statistical analysis required.

\section{Results}

The laboratory investigations of serum ferritin was done among the 50 subjects. It was expressed as mean \pm SD and the results were expressed in SI units. The mean age of the 50 subjects were 52,25 \pm 9.95 ranging from $43-60$ years. The age of control subjects were $52.35 \pm 10.46$ ranging from 42-62 years and the age of MI subjects were 55,43 \pm 10.79 ranging from $45-65$ yars. The distribution of the subjects by sex was studied. Among control subjects 19 were male and 11 were female and in MI patients 13 were male and 7 were female. ANOVA test was done in case of age and sex of the subjects. There is no statistically significant difference was observed among the study subjects $B>0.05$ (Table-1). The mean level of scrum ferritin of control subjects were 111.65 $\pm 50.47 \mathrm{ng} / \mathrm{ml}$ and in test subjects the mean level of serum ferritin were $258.44 \pm 87.87 \mathrm{ng} / \mathrm{ml}$. A highly significant mean difference $(P<0.001)$ wils found in serum ferritin level between the groups of test and control subjects through the analysis of variance (ANOVA) test of significance of difference (Table-2).

Table 1: Age, sex and economic status of different groups of the study subjects.

\begin{tabular}{llccl}
\hline Group & Age (in year) & \multicolumn{2}{c}{ Sex } & Income (in Taka) \\
\hline & & Male & Female & \\
\hline Group A $(\mathrm{n}=30)$ & $52.35 \pm 10.46$ & 19 & 11 & $6000(2000-25000)$ \\
Group B $(\mathrm{u}=20)$ & $55.43 \pm 10.79$ & 13 & 7 & $5000(2000-21000)$ \\
F/p value & $1.69 / 0.194$ & & & $0.702 / 0.500$ \\
\hline
\end{tabular}

Statistical comparison of mean age, sex \& economic status of different groups was done. No statistical mean difference was found ainong the study groups $(P>0.05)$.

Table-2: Serum ferritin level of the different group of study subjects.

\begin{tabular}{ll}
\hline \multicolumn{1}{c}{ Group } & Serum ferritin ng/ml \\
\hline Group A $(\mathrm{n}=30)$ & $111.65 \pm 50.47$ \\
Group B $(\mathrm{n}=20)$ & $258,44 \pm 87.87$ \\
F/p value (ANOVA) & $24.16 / 0.001^{* * *}$ \\
\hline
\end{tabular}

Statistical comparison of mean serum ferritin level between different groups was done. There was stausticalty highty significant mean difference between group A vs group B ( $\left.{ }^{* *: *} p<0.001\right)$

\section{Discussion}

The present study was carried out to compare serum ferritin in patients with MI and those of control subjects. Association of increased serum ferritin with $\mathrm{Ml}$ have been observed in series of studies. But it is still in dilemma whether serum

ferritin is a risk factor for developing MI. Studies investigating whether iron status can be considered as a cardiovascular risk factor presented conflicting results, as reviewed recently. This was not unexpected because none of the indicators of iron status evaluated hemoglobin, hematocrit. serum iron, transferrin, total iron binding capacity accurately reflects body iron. Because serum ferritin concentration are directly proportional to intracellular ferritin concentration, it is considered to be the best clinical measure of body iron stores. However, so far only a few studies evaluated serum ferritin concentration to examine whether body iron stores are associated with cardiovaseular. disease.

So in our study we have measured serum ferritin concentration as the best clinical measure of body iron stores. We have observed the mean serum 
ferritin level in MI patients was significantly higher than the normal healthy subjects. This finding indicate that high serum ferritin concentration may increase the risk of MI. Basic research has provided strong evidence that LDL oxidation plays an important role in the pathogenesis of atherosclerosis and cardiovascular disease ${ }^{8}$ LDL oxidation can be enhanced by metal catalyzed reaction, resulting in highly reactive hydroxyl radicals. Superoxide anions produced by oxidative stress and reducing agents have been found to be capable of mobilizing iron from ferritin. In conclusion, we observed elevated serum ferritin concentration to be associated with increased risk of MI. It may be possible that elevated body iron stores may accelerate atherogenesis by stimulating the oxidation of LDLS.

\section{Conclusion}

The present study showed that serum ferritin level is significantly higher in patients with MI. From the present work, it is difficult to draw any definite conclusion but suggested that high serum ferritin concentration level may be responsible for MI. So, it may be recommended for estimation of serum ferritin along with other major risk factors for better management of $\mathrm{Ml}$ patients. But further study involving a larger sample size, may be carried out to draw a definite conclusion.

\section{References}

1. Addison GM. Assay for in the serum. I Clin Pathol $1972 ; 25 ; 326-329$.

2. Ali SM, Hossian AM, Islam K, Khatun N. Normal blood pressure of Bangladeshi adults. Bangladesh Heart Joumal $1997 ; 12 ; 3-7$.

3. Boon NA, Fox KA, Bloomfield $P$. Dieases of the cardiovascular system. In: Haslet $C$, Chilvers EA, Hunter JA. Boon NA, eds, Davidson's Principles and Practice of Medicinec $18^{\text {th }}$ edn. Churchill Livingstone: $191-302$.

4. Chowdhury BK. Studies on serum Magnesium and Potassium in Ischemic heart disease. Thesis 2001 Department of Biochemistry, Bangbandhu Sheikh Mujeb Medical University, Dhakà, Bangladesh.

5. Ross R. The pathogenesis of atherosclerosis: an update. N Engl J Med 1986; 314:488-500.

6. Champe PC, Harvey RA, Nutrition. In: Champe PC. Harvey RA, eds, Lippincolt's Illustrated Reviews: Blochemistry, $2^{\text {nit }}$ end, Lippincot-Paven Publishers, JB Lippicot Company, Philadelphla $1994 ; 303-318$

7. Evenson MA. Spectropholometer Techniques. In: Burtis CA, Ashwood ER. eds, Tietz textbook of Clinical Chemistry, $3^{\text {id }}$ edn, WB Saunders Company, USA 1999; 75-93.

8. Collins R. Etiology of sudden of ischemic heart disease. Science 1980; 208:198-200

All correspondence to:

Md. Samiul Hafiz Lecturer

Department of Biochernistry

Rajshahi Medical College

Rojshahi. 